\title{
Correlation Study For the Assessment of Water Quality and Its Parameters of Ganga River, Kanpur, Uttar Pradesh, India
}

\author{
Naseema Khatoon ${ }^{* 1}$, Altaf Husain Khan ${ }^{* * 2}$ Masihur Rehman ${ }^{3}$ Vinay Pathak ${ }^{4}$ \\ 1 Department of Chemistry, Integral University, Dasauli, Kursi Road, Lucknow \\ 2 Indian Institute of Toxicology Research, Mahatma Gandhi Marg, Lucknow
}

\begin{abstract}
In the present work water samples are collected from six different Ghats of Ganga river in Kanpur city from March 2010 to February 2011 on monthly basis and water quality assessment is carried out. Pearson's correlation coefficient ( $r$ ) value is determined using correlation matrix to identify the highly correlated and interrelated water quality parameters. To test the significance of the pair of parameters p-value is carried out and in order to test the joint effects of several independent variables, without frequent or repeated monitoring of water quality in a location. Higher concentration of Chromium $(6.7 \mathrm{mg} / \mathrm{l})$ at Siddhnath ghat in June, and its monthly variation showed highly adverse effect on river Ganga due to tanneries effluent. It is found that significant positive correlation holds for Temp vs BOD GH1 ( $r=0.99, p<0.01)$, EC vs chloride GH6 $(r=0.877, p<0.01)$, EC vs TDS GH6 ( $r=0.836, p<0.01)$; and TA vs DO GH1 $(r=0.842, p<0.01), p H$ vs Mg GH6 $(r=-0.79, p<0.01), E C$ vs Nitrate GH6 ( $r=0.846, p<0.01)$. A significant negative correlation was found for DO vs BOD GH3 ( $r=-0.943, p<0.01)$, DO vs TDS GH6 $(r=-0.838, p<0.01)$, and TA vs TDS GH6 $(r=-0.88, p<0.01)$. Chromium is found that non significant correlation. The mean values of all the measured physico-chemical parameters of Ganga river water are within the highest desirable limit set by WHO except BOD.
\end{abstract}

Keywords: BIS, Pearson correlation, p-value, Water quality, WHO,

\section{Introduction:}

River pollution in India has now reached to a point of crisis. The entire array of life in water is affected due to pollution in water. Rivers are vital and vulnerable freshwater ecosystems that are critical for the sustenance of all life. However, the declining water quality of these ecological systems threatens their sustainability and is therefore a matter of serious concern. People along the river use water for many purposes. However, the surface water quality is deteriorating due to anthropogenic activities such as urbanization, industrialization, transportation, farming, disposal of animal and human excretions and domestic wastes in to water bodies [1]. Surface waters are most vulnerable to pollution due to their easy accessibility for disposal of wastewaters. In India the river systems are getting polluted day by day. In many parts of the world the polluted water from river is used for irrigation without assessing its suitability. Today acute pollution prevails in many rivers such as Krishna, Tapti, Brahmaputra, Ganga, Hooghly and Brahmani etc.

During its journey in indo-Gangetic plain Ganga river passes through industrial city of Kanpur. The industrial areas in Kanpur are situated in the midst of densely populated regions, along the banks of the Ganga river. As the river flows along the city it receives huge amount of domestic sewage and industrial effluent. It also receives tannery waste in its last segment in the city. The tannery operation consists of converting of the raw hide or skin into leather, consequently, make it as a potentially pollution intensive industry. The tannery effluent has chemical impurities and the most toxic heavy metal like Chromium $(\mathrm{Cr})$. Researcher reported increased investment to improve the capacity and technology of STP (Sewage Treatment Plans) to reduce water pollution [2]. It is a cumbersome task to regularly monitor all the parameters even if adequate manpower and laboratory facilities are available. Therefore, in recent years an easier and simpler approach based on statistical correlation, has been developed using mathematical relationship for comparison of physico-chemical parameters. Extensive research has been carried out on statistical analysis to assess the surface water quality. Joshi et.al [3], have assessed the water quality characteristics of River Ganga in Haridwar, India using Person's Correlation. Trivedi et.al has studied the Physico-Chemical characteristics of Ganga river at Kanpur by using correlation approach [4]. Statistical analysis of physico-chemical parameters of water has been reported from the different parts of India [5-9]. In the present study an attempt has, been made to assess water quality of Ganga river in Kanpur district, Uttar Pradesh in India.

\section{Materials And Methods}

\subsection{Description of study Area:}

Kanpur is a densely populated city has a population of 2,920,067 as per 2011 census[10].It is known as Manchester of the East, the largest industrial hub of Uttar Pradesh State in India. It is bounded by 26.28 degree North latitude and 80.21 degree East longitude. Kanpur is situated on the western bank of the river Ganga. A 
thorough survey of river stretch of $24 \mathrm{~km}$ from the entry point to exit point of river in Kanpur city was carried to record pollution sources and to identify the sampling locations. The samples were collected for a period of twelve months from March 2010 to February 2011 from six sites reasonably representing the water quality of the river system. The selected sampling sites and observed pollution sources at each site are as follows:

- Bithoor ghat (GH1) - It receives moderate amount of domestic pollution.

- Rani ghat (GH2) - It receives municipal waste from the locality.

- Permat ghat (GH3) - The drain is discharging burned ashes directly into Ganga river.

- Sarsaiya ghat (GH4) - It receives huge amount of domestic sewage.

- Nanarao ghat (GH5) - It receives contamination through urban sewage.

- Siddhnath ghat (GH6) - It is polluted due to tannery discharge and untreated waste.

\section{Sampling And Analysis}

Physico-chemical parameters and chromium levels in water samples were determined according to APHA 1998. Electrical conductivity, $\mathrm{pH}$ and dissolved oxygen of water samples were measured in the field immediately after collection of the samples using $\mathrm{pH}$, conductivity and DO meter respectively. Biological oxygen demand (BOD) was determined by conventional methods and Total Dissolved Solids were determined using the gravimetric method. The metal concentration of chromium $(\mathrm{Cr})$, in the filtered and digested samples was determined using flame Atomic Absorption Spectrophotometer (AAS).

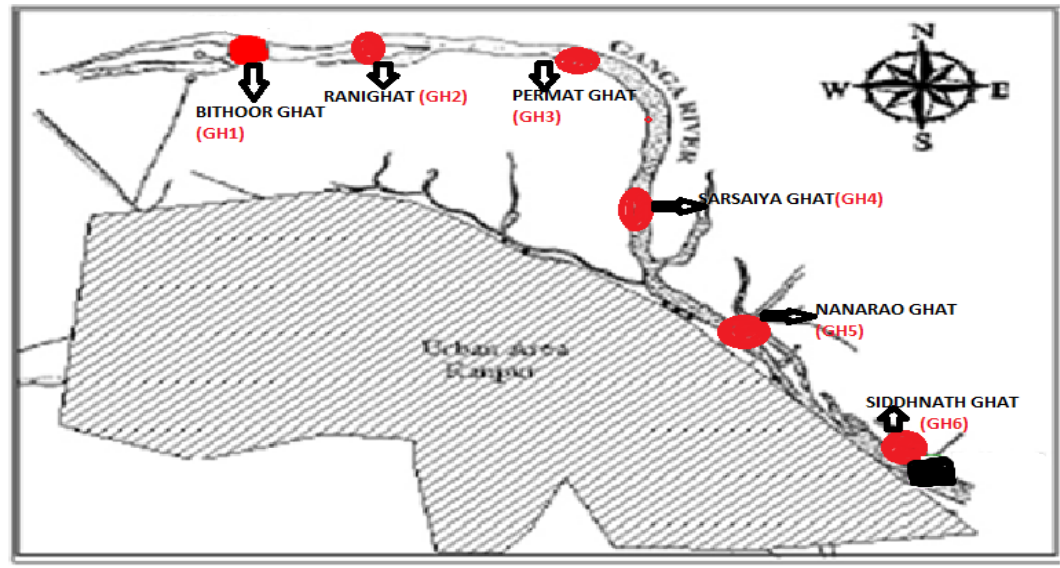

Fig: 1 - Location of Ganga river water sampling points around Kanpur

\section{Statistical Analysis}

Statistical analysis was carried out using statistical package for social sciences [11] (SPSSVersion17). The physico-chemical parameters for all the study sites were analyzed by calculating Pearson's correlation coefficient (r) value. In order to calculate correlation coefficients, correlation matrix was constructed by calculating the coefficients of different pairs of parameters and correlation for significance was further tested by applying $p$ valve. The variations are significant if $p<0.05, p<0.01$, and non-significant if $p>0.05$. The significance is considered at the level of 0.01 and 0.05 (2-tailed analysis).

\section{Results And Discussion}

The statistical result with respect to range, mean, minimum, maximum, SD and SE values for surface water quality with WHO \& BIS standards parameters are summarized in Table 1. Graphical Monthly variation of physico-chemical parameters for surface water are represented in figures The statistical results for various physicochemical parameters were depicted in table 2, 3, 4, 5, 6 and 7 for surface water with correlation matrix.

\begin{tabular}{|c|c|c|c|c|c|c|c|c|}
\hline \multicolumn{9}{|c|}{ Table1:Statistical summary of surface water quality of river Ganga $(n=72)$} \\
\hline Parameters & Range & Mean & Min & Max & SD & SE & WHO & BIS \\
\hline Temperature $(0 \mathrm{C})$ & $15.4-32.9$ & 23.25 & $\begin{array}{l}\mathrm{GH} 4 \\
\text { Jan }\end{array}$ & GH2 Jun & 4.97 & 0.6 & NA & NA \\
\hline $\mathrm{pH}$ & $7.1-8.8$ & 7.99 & GH4 Jul & GH6 Dec & 0.44 & 0.1 & $6.5-8.5$ & $6.5-8.5$ \\
\hline Alkalinity (mg/l) & $232-337$ & 273 & GH4 Jul & GH5 Jan & 24.7 & 2.9 & $200-600$ & 200 \\
\hline DO (mg/l) & $2.6-14.4$ & 6.83 & $\begin{array}{l}\text { GH6 } \\
\text { Jun }\end{array}$ & GH1 Feb & 2.8 & 0.3 & $6-F e b$ & 6 \\
\hline $\mathrm{BOD}(\mathrm{mg} / \mathrm{l})$ & $2.6-32.4$ & 19.62 & $\begin{array}{l}\text { GH1 } \\
\text { Jan }\end{array}$ & GH6 Sept & 8.1 & 1 & 3 & $<3.0$ \\
\hline TDS (mg/l) & $148-300$ & 242.4 & $\begin{array}{l}\text { GH1 } \\
\text { Jun }\end{array}$ & GH6 Jul & 33.3 & 3.9 & $\begin{array}{l}500- \\
1500\end{array}$ & 500 \\
\hline
\end{tabular}


Correlation Study For The Assessment Of Water Quality and Its Parameters Of Ganga River,Kanpur,

\begin{tabular}{|l|l|l|l|l|l|l|l|l|} 
Chloride (mg/l) & $8.3-25.7$ & 14.5 & $\begin{array}{l}\text { GH4 } \\
\text { Oct }\end{array}$ & GH6 Jun & 4.31 & 0.5 & $\begin{array}{l}250- \\
1000\end{array}$ & 250 \\
\hline Ec $\mu \mathrm{s} / \mathrm{cm}$ & $198-465$ & 311.19 & $\begin{array}{l}\text { GH3 } \\
\text { Jan }\end{array}$ & GH5Jun & 65.9 & 7.8 & NA & \\
\hline Nitrate $(\mathrm{mg} / \mathrm{l})$ & $0.35-0.98$ & 0.33 & $\begin{array}{l}\text { GH1 } \\
\text { Jan }\end{array}$ & GH6 Jun & 0.32 & 0 & 50 & \\
\hline Phosphate $(\mathrm{mg} / \mathrm{l})$ & $0.12-1.56$ & 0.57 & $\begin{array}{l}\text { GH1 } \\
\text { Dec }\end{array}$ & GH6 Jun & 0.41 & 0 & 0.5 & \\
\hline Chromium $(\mathrm{mg} / \mathrm{l})$ & $0.085-6.7$ & 0.69 & $\begin{array}{l}\text { GH1 } \\
\text { Nov }\end{array}$ & GH6 Jun & 1.11 & 0.1 & 0.05 & \\
\hline Magnesium $(\mathrm{mg} / \mathrm{l})$ & $6.2-24.2$ & 12.82 & $\begin{array}{l}\text { GH1 } \\
\text { Jan }\end{array}$ & GH6 Jun & 4.51 & 0.5 & $30-150$ & \\
\hline
\end{tabular}

Water Temperature: During the whole study period (at all sampling locations) the max water temperature $32.9^{\circ} \mathrm{C}$ was recorded in GH6 (June) and $\min 15.4^{\circ} \mathrm{C}$ in GH4 (January) with an annual mean of $23.25^{\circ} \mathrm{C} \pm 5.85$ (Table 1, Fig 2). The variation is mainly related with the atmosphere temperature and weather conditions. Higher temperature during June was due to greater heating [12].

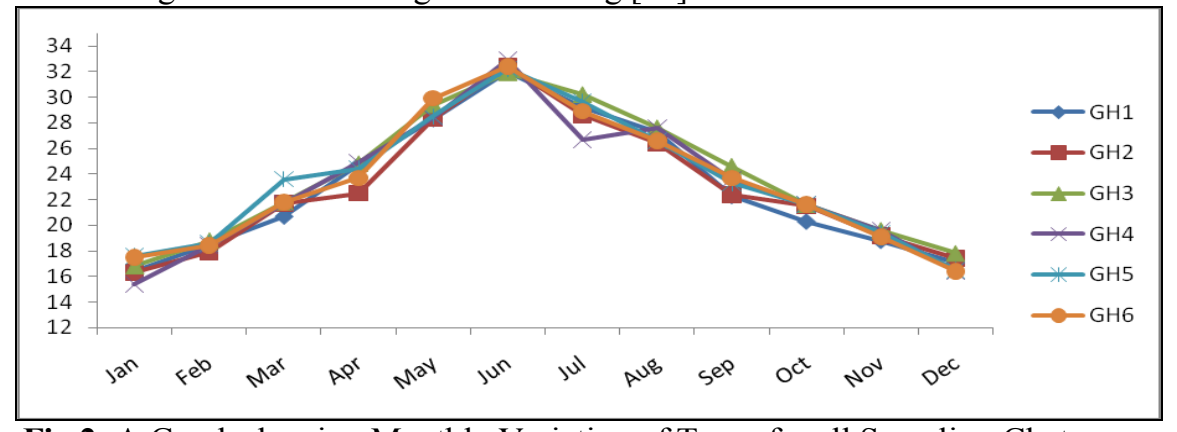

Fig 2: A Graph showing Monthly Variation of Temp for all Sampling Ghats

The Water temperature (Temp) showed significant and positive correlation with TDS, BOD, Chloride, EC, Nitrate, Phosphate and, Magnesium. The Temp vs. TDS showed max correlation at GH6 ( $\mathrm{r}=0.889, \mathrm{p}<0.01)$ and $\min$ at GH3 ( $r=0.755, \mathrm{p}<0.01)$, Temp vs BOD showed max correlation at GH1 $(\mathrm{r}=0.99, \mathrm{p}<0.01)$ and $\min$ at $\mathrm{GH} 3(\mathrm{r}=0.719, \mathrm{p}<0.05)$, Temp vs. Chloride showed max correlation at $\mathrm{GH} 1(\mathrm{r}=0.872, \mathrm{p}<0.01)$ and $\mathrm{min}$ at $\mathrm{GH} 2$ $(\mathrm{r}=0.799, \mathrm{p}<0.01)$, Temp vs. EC showed max correlation at GH4 $(\mathrm{r}=0.896, \mathrm{p}<0.01)$ and $\min$ at GH5 $(\mathrm{r}=0.773$, $\mathrm{p}<0.01)$, Temp vs. Nitrate showed max correlation at GH2 $(\mathrm{r}=0.935, \mathrm{p}<0.01)$ and min at GH1 $(\mathrm{r}=0.774, \mathrm{p}<0.01)$, Temp vs. Phosphate showed max correlation at GH6 $(\mathrm{r}=0.996, \mathrm{p}<0.01)$ and $\min$ at $\mathrm{GH} 2(\mathrm{r}=0.712, \mathrm{p}<0.01)$, Temp vs. Magnesium showed max correlation at GH6 ( $(\mathrm{r}=0.982, \mathrm{p}<0.01)$ and $\min$ at GH6 $(\mathrm{r}=0.93, \mathrm{p}<0.01)$.

The Water Temp showed significant and negative correlation with $\mathrm{pH}, \mathrm{DO}$ and TA. The Temp vs. $\mathrm{pH}$ showed max correlation at GH6 $(\mathrm{r}=-0.89, \mathrm{p}<0.01)$ and $\min$ at GH4 $(\mathrm{r}=-0.621, \mathrm{p}<0.05)$, Temp vs. DO showed max correlation at GH6 $(\mathrm{r}=-0.90, \mathrm{p}<0.01)$ and $\mathrm{min}$ at $\mathrm{GH} 2(\mathrm{r}=-0.759, \mathrm{p}<0.05)$. Temp vs TA showed max correlation at GH6 $(\mathrm{r}=-0.792, \mathrm{p}<0.01)$ and $\min$ at GH4 $(\mathrm{r}=-0.681, \mathrm{p}<0.05)$. It can be observed that DO has a negative correlation with Temp for all the locations. The inverse relationship between Temp and DO is a natural process as warmer water becomes more easily saturated with oxygen and holds less DO [13].

pH: The presence of hydrogen ion concentration is measured in terms of $\mathrm{pH}$ range. In our investigation the $\mathrm{pH}$ value of surface water ranged from 7.1 to 8.8 , indicating that the nature of water is slightly basic to strong basic. The min pH recorded at GH4 (July), while the max at GH6 (December) with an annual mean of $7.98 \pm .436$, which was above the higher permissible range, prescribed by BIS [14] and WHO [15] drinking water standards (Table 1, Fig 3). It has been mentioned that the increasing $\mathrm{pH}$ appear to be associated with increasing use of alkaline detergents in residential areas and alkaline material from tannery effluent [16].

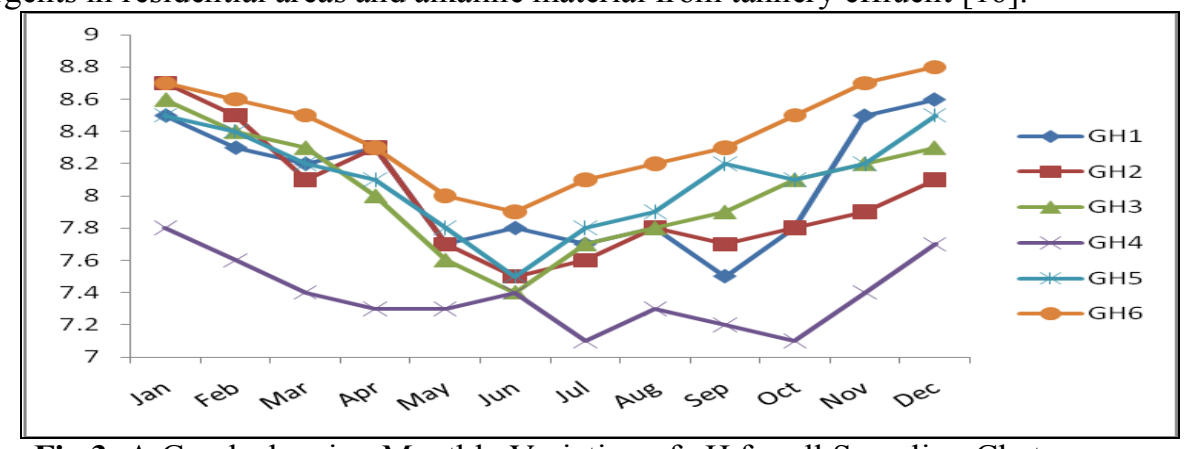

Fig 3: A Graph showing Monthly Variation of $\mathrm{pH}$ for all Sampling Ghats 
The $\mathrm{pH}$ showed significant and positive correlation with TA and DO. A strong positive correlation of $\mathrm{pH}$ vs. DO in the water of Gomti river (flowing in the same geographical region) was also observed [17]. The pH vs TA showed max correlation at GH4 $(\mathrm{r}=0.824, \mathrm{p}<0.01)$ and $\min$ at $\mathrm{GH} 3(\mathrm{r}=0.651, \mathrm{p}<0.05)$, $\mathrm{pH}$ vs. DO showed max correlation at GH3 $(\mathrm{r}=0.887, \mathrm{p}<0.01)$ and $\min$ at $\mathrm{GH} 5(\mathrm{r}=0.713, \mathrm{p}<0.01)$.

The $\mathrm{pH}$ showed significant and negative correlation with BOD, TDS, Chloride, EC, Nitrate, Phosphate and Magnesium. The $\mathrm{pH}$ vs. BOD showed max correlation at GH5 ( $\mathrm{r}=-0.854, \mathrm{p}<0.01)$ and $\min$ at $\mathrm{GH} 2(\mathrm{r}=-$ $0.664, \mathrm{p}<0.05), \mathrm{pH}$ vs. TDS showed max correlation at GH1 $(\mathrm{r}=-0.95, \mathrm{p}<0.01)$ and $\min$ at $\mathrm{GH} 3(\mathrm{r}=-0.721$, $\mathrm{p}<0.05)$ and $\mathrm{pH}$ vs. Chloride showed max correlation at GH5 $(\mathrm{r}=-0.799, \mathrm{p}<0.01)$ and $\min$ at GH1 $(\mathrm{r}=-0.636$, $\mathrm{p}<0.05)$, $\mathrm{pH}$ vs. EC showed max correlation at GH6 $(\mathrm{r}=-0.838, \mathrm{p}<0.01)$ and $\min$ at $\mathrm{GH} 4(\mathrm{r}=-0.676, \mathrm{p}<0.01), \mathrm{pH}$ vs. Nitrate showed max correlation at $\mathrm{GH} 3(\mathrm{r}=-0.964, \mathrm{p}<0.01)$ and $\min$ at $\mathrm{GH} 1(\mathrm{r}=-0.727, \mathrm{p}<0.01)$, $\mathrm{pH}$ vs. Phosphate showed max correlation at GH6 $(\mathrm{r}=-0.963, \mathrm{p}<0.01)$ and $\min$ at GH4 $(\mathrm{r}=-0.677, \mathrm{p}<0.01)$, $\mathrm{pH}$ vs. Magnesium showed max correlation at GH6 $(\mathrm{r}=-0.979, \mathrm{p}<0.01)$ and $\min$ at $\mathrm{GH} 4(\mathrm{r}=0.703, \mathrm{p}<0.01)$.

Dissolved Oxygen (DO): DO is one of the important parameter in water quality assessment. In our study DO of surface water ranged from 2.6 to $14.4 \mathrm{mg} / \mathrm{l}$. The min DO recorded at GH6 (June) and the max was noted at GH1 (February), with an annual mean of $6.8 \pm 2.8$ which was above the max permissible range as prescribed by BIS[14] and WHO[15] drinking water standards (Table 1,Fig 4).

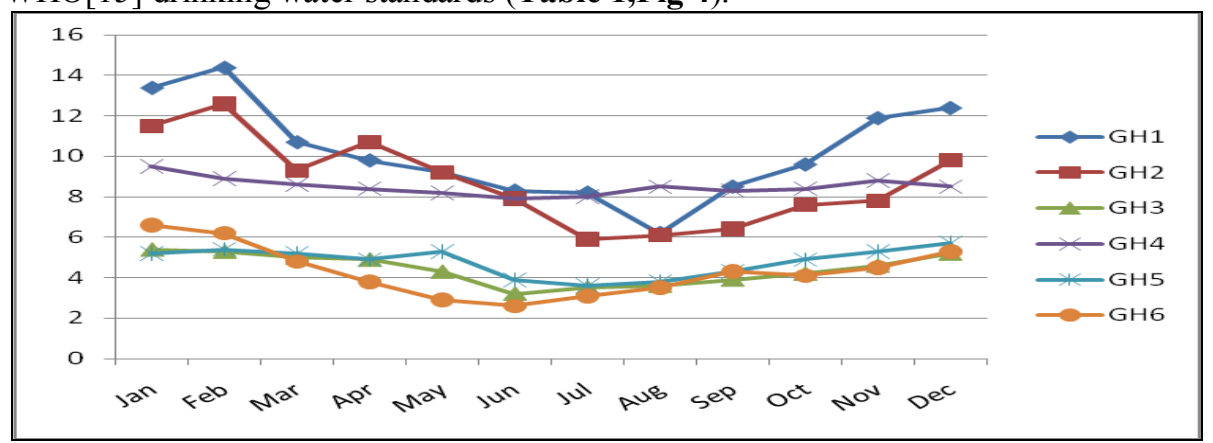

Fig 4: A Graph showing Monthly Variation of DO for all Sampling Ghats

The DO showed significant and negative correlation with BOD, TDS, Chloride, EC, Nitrate, Phosphate, and Magnesium. Similar findings are reported by the other author [18]. DO showed max correlation with BOD at GH3 $(r=-0.943, p<0.01)$ and $\min$ at GH6 $(r=-0.703, p<0.01)$, DO vs. TDS showed max correlation at GH6 ( $r=-$ $0.960, \mathrm{p}<0.01)$ and $\min$ at $\mathrm{GH} 4(\mathrm{r}=-0.807, \mathrm{p}<0.01)$. These findings are similar to the reported relationship, that low DO usually depicts a high TDS values[19] DO vs. Chloride showed max correlation at GH6 $(\mathrm{r}=-0.771$, $\mathrm{p}<0.01)$ and $\min$ at GH4 $(\mathrm{r}=-0.659, \mathrm{p}<0.01)$, DO vs. EC showed max correlation at GH1 $(\mathrm{r}=-0.828, \mathrm{p}<0.01)$ and min at GH5 $(\mathrm{r}=-0.625, \mathrm{p}<0.05)$, DO vs. Nitrate showed max correlation at GH1 $(\mathrm{r}=-0.870, \mathrm{p}<0.01)$ and min at GH4 ( $\mathrm{r}=0.613, \mathrm{p}<0.01)$, DO vs. Phosphate showed max correlation at GH3 $(\mathrm{r}=-0.967, \mathrm{p}<0.01)$ and $\min$ at GH5 $(\mathrm{r}=-0.723, \mathrm{p}<0.01)$, DO vs. Magnesium showed max correlation at GH6 $(\mathrm{r}=-0.786, \mathrm{p}<0.01)$ and $\min$ at $\mathrm{GH} 3(\mathrm{r}=-$ $0.630, \mathrm{p}<0.01)$.

Total Alkalinity (TA): The cause of total alkalinity in water is the presence of various ions. The observed mean was $273 \pm 24.68 \mathrm{mg} / \mathrm{l}$ and values alkalinity ranged 232-337 mg/l. At sampling ghat GH4 (July) recorded low value, while at GH5 (Jan) it was high. These values are within max permissible limit prescribed by WHO $^{\mathbf{1 5}}$ (Table 1, Fig 5). Excessive alkalinity may cause eye irritation in human. If alkalinity value in drinking water is higher than $200 \mathrm{mg} / \mathrm{l}$, the taste of the water becomes unlikable.

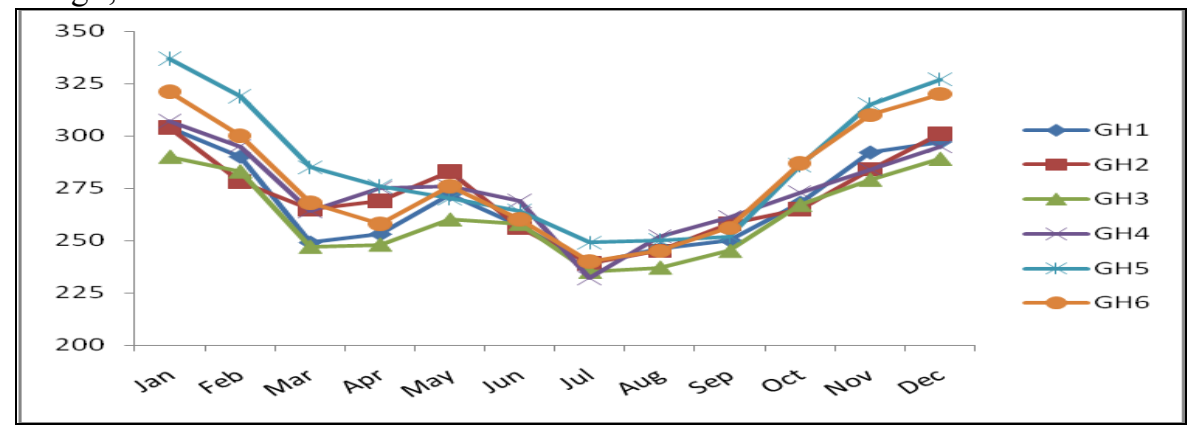

Fig 5: A Graph showing Monthly Variation of TA for all Sampling Ghats 
The TA showed positive and significant correlation with DO max at GH1 $(r=0.842, p<0.01)$ and min at GH3 $(\mathrm{r}=0.683, \mathrm{p}<0.05)$. The TA showed significant and negative correlation with BOD, TDS, Chloride, EC, Nitrate, Phosphate, and Magnesium. The TA showed max correlation with BOD at GH6 $(\mathrm{r}=-0.84, \mathrm{p}<0.01)$ and min at GH3 $(\mathrm{r}=-0.663, \mathrm{p}<0.05)$, TA vs. TDS showed max correlation at GH6 $(\mathrm{r}=-0.88, \mathrm{p}<0.01)$ and $\min$ at GH4 $(\mathrm{r}=-$ $0.552, \mathrm{p}<0.05)$, TA vs. Chloride showed max at GH4 $(\mathrm{r}=-0.659, \mathrm{p}<0.01)$ and $\min$ at GH3 $(\mathrm{r}=-0.423, \mathrm{p}<0.05)$, TA vs. EC showed max correlation at GH4 $(\mathrm{r}=-0.897, \mathrm{p}<0.01)$ and min value at $\mathrm{GH} 4(\mathrm{r}=-0.697, \mathrm{p}<0.05)$, TA vs. Nitrate showed max correlation at GH3 $(\mathrm{r}=-0.870, \mathrm{p}<0.01)$ and $\min$ at GH4 $(\mathrm{r}=-0.613, \mathrm{p}<0.05)$, TA vs. Phosphate showed max correlation at GH6 $(\mathrm{r}=-0.868, \mathrm{p}<0.01)$ and $\min$ at GH1 $(\mathrm{r}=-0.737, \mathrm{p}<0.01)$, TA vs. Magnesium showed max correlation at GH6 $(\mathrm{r}=0.786, \mathrm{p}<0.01)$ and $\min$ at $\mathrm{GH} 3(\mathrm{r}=0.630, \mathrm{p}<0.05)$.

Biological Oxygen Demand (BOD): BOD is an important parameter of water indicating the health scenario of freshwater bodies [20]. In our study the BOD of surface water ranges from $2.6 \mathrm{mg} / 1$ to $32.4 \mathrm{mg} / 1$ with an annual mean of $19.6 \pm 8.09$. The min BOD recorded at GH1 (Jan) and the max value was noted on GH6 (Sept), which was above the max permissible range as prescribed by $\mathrm{BIS}^{\mathbf{1 4}}$ and $\mathrm{WHO}^{\mathbf{1 5}}$ drinking water standards (Table 1, Fig 6). BOD values were not complying with WHO guide lines in the river Ganga.

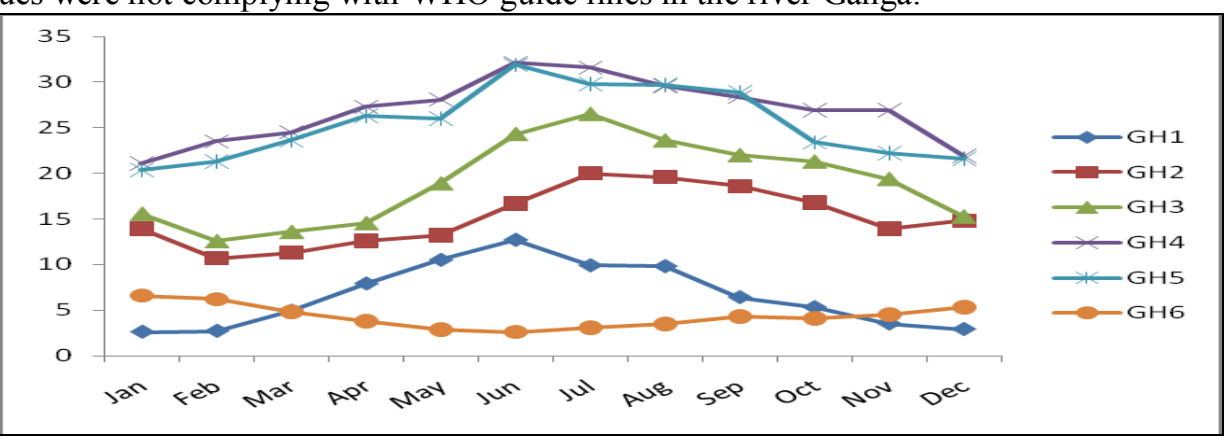

Fig 6: A Graph showing Monthly Variation of BOD for All Sampling Ghats

The BOD showed significant and positive correlation with TDS, Chloride, EC, Nitrate, Phosphate and Magnesium. BOD vs. TDS showed max correlation value at GH5 ( $\mathrm{r}=0.954, \mathrm{p}<0.01)$ and $\min$ at GH2 $(\mathrm{r}=0.751$, $\mathrm{p}<0.01)$, BOD vs. Chloride showed max correlation value at GH1 $(\mathrm{r}=0.853, \mathrm{p}<0.01)$ and $\min$ at $\mathrm{GH} 6(\mathrm{r}=0.614$, $\mathrm{p}<0.05)$, BOD vs. EC showed max correlation at GH1 $(\mathrm{r}=0.831, \mathrm{p}<0.01)$ and $\min$ at $\mathrm{GH} 6(\mathrm{r}=0.614, \mathrm{p}<0.05)$, BOD vs. Nitrate showed max correlation at GH4 $(\mathrm{r}=0.838, \mathrm{p}<0.01)$ and $\min$ at $\mathrm{GH} 2(\mathrm{r}=0.529, \mathrm{p}<0.05)$, BOD vs. Phosphate showed max correlation at GH4 $(\mathrm{r}=0.983, \mathrm{p}<0.01)$ and $\min$ at GH6 $(\mathrm{r}=0.832, \mathrm{p}<0.01)$, BOD vs. Magnesium showed max correlation at GH1 $(\mathrm{r}=0.995, \mathrm{p}<0.01)$ and $\min$ at $\mathrm{GH} 2(\mathrm{r}=0.578, \mathrm{p}<0.05)$.

Total Dissolved Solids (TDS): The total dissolved solids are expressed by the weight of residue left when a water sample has been evaporated to dryness. The range of TDS varied from 148 to $300 \mathrm{mg} / \mathrm{l}$ in the study. The min value recorded at sampling ghat GH1 (Jan) and max value was recorded at GH6 (July) with an annual mean of $242.4 \pm 33.34$, which was within the permissible limit prescribed by BIS[14] and WHO[15] standard (Table 1,Fig 7). Bhadula and Joshi studied the impact of sewage on main canal of river Ganga at Haridwar, pointed out that the total solids were higher in the sewage zone in comparison to dilution zone [21].

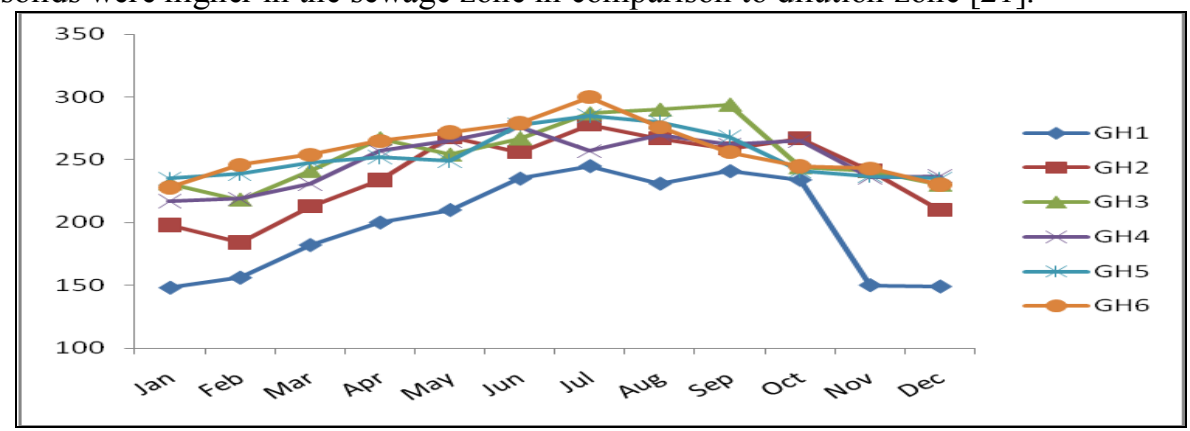

Fig 7: A Graph showing Monthly Variation of TDS for all Sampling Ghats

The TDS showed significant and positive correlation with Chloride, EC, Nitrate, Phosphate and Magnesium. TDS showed positive and significant max correlation with Chloride at GH5 $(\mathrm{r}=0.756, \mathrm{p}<0.01)$ and $\mathrm{min}$ at $\mathrm{GH} 2$ $(\mathrm{r}=0.460, \mathrm{p}<0.01)$, TDS vs. EC showed max correlation at GH6 $(\mathrm{r}=0.836, \mathrm{p}<0.01)$ and $\min$ at $\mathrm{GH} 2(\mathrm{r}=0.715$, $\mathrm{p}<0.01$ ). Similarly TDS has a positive correlation with conductivity in all stations because conductivity variation reflects the status of inorganic pollution and is a measure of TDS in water [22]. TDS vs. Nitrate showed max 
correlation at GH6 $(\mathrm{r}=0.868, \mathrm{p}<0.01)$ and $\min$ at GH4 $(\mathrm{r}=0.722, \mathrm{p}<0.01)$, TDS vs. Phosphate showed max correlation at GH6 $(\mathrm{r}=0.919, \mathrm{p}<0.01)$ and $\min$ at GH5 $(\mathrm{r}=0.788, \mathrm{p}<0.01)$, TDS vs. Magnesium showed max correlation at GH6 $(\mathrm{r}=0.935, \mathrm{p}<0.01)$ and $\min$ at $\mathrm{GH} 3(\mathrm{r}=0.690, \mathrm{p}<0.05)$. Similar finding were reported by other researcher [23].

Chloride: In the present study the Chloride concentration in surface water was $14.50 \pm 4.31 \mathrm{mg} / 1$ (range 8.3-25.7 $\mathrm{mg} / \mathrm{l}$ ). The min Chloride observed at GH4 (Oct) and the max at GH6 (June). All the observed values were within the permissible range as prescribed by BIS14 and WHO15 drinking water standards (Table 1, Fig 8).

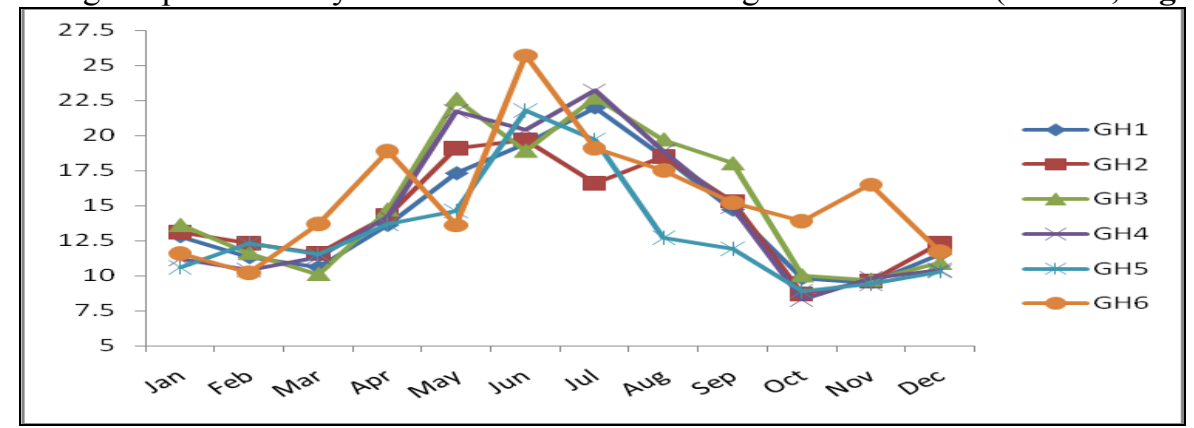

Fig 8: A Graph showing Monthly Variation of Chloride for all Sampling Ghats

The Chloride showed significant and positive correlation with EC, Nitrate, Phosphate and Magnesium. Chloride vs. EC showed max correlation at GH6 $(\mathrm{r}=0.877, \mathrm{p}<0.01)$ and $\min$ at GH5 $(\mathrm{r}=0.529, \mathrm{p}<0.01)$, Chloride vs. Nitrate showed max correlation at GH4 $(\mathrm{r}=0.812, \mathrm{p}<0.01)$ and $\min$ at GH1 $(\mathrm{r}=0.583, \mathrm{p}<0.05)$, Chloride vs. Phosphate showed max at GH3 $(r=0.828, \mathrm{p}<0.01)$ and $\min$ at GH2 $(\mathrm{r}=0.585, \mathrm{p}<0.05)$, Chloride vs. Magnesium showed max correlation at GH5 $(r=0.879, \mathrm{p}<0.01)$ and $\min$ at GH6 $(r=0.729, \mathrm{p}<0.01)$.

Electrical Conductivity (EC): EC is the measure of capacity of a substance or solution to conduct electrical current through the water. The range of EC varied from 198-465 $\mu \mathrm{s} / \mathrm{cm}$ with an average of $311.19 \pm 65.94 \mu \mathrm{s} / \mathrm{cm}$ in this study. The min and max value were reported at the GH1 (Jan) and GH5 (June) (Table 1, Fig 9). The max value is above the upper limit prescribed by BIS14 standard. High conductivity at the sites indicates the mixing of sewerage in river water as these sites are located near populated towns [24]

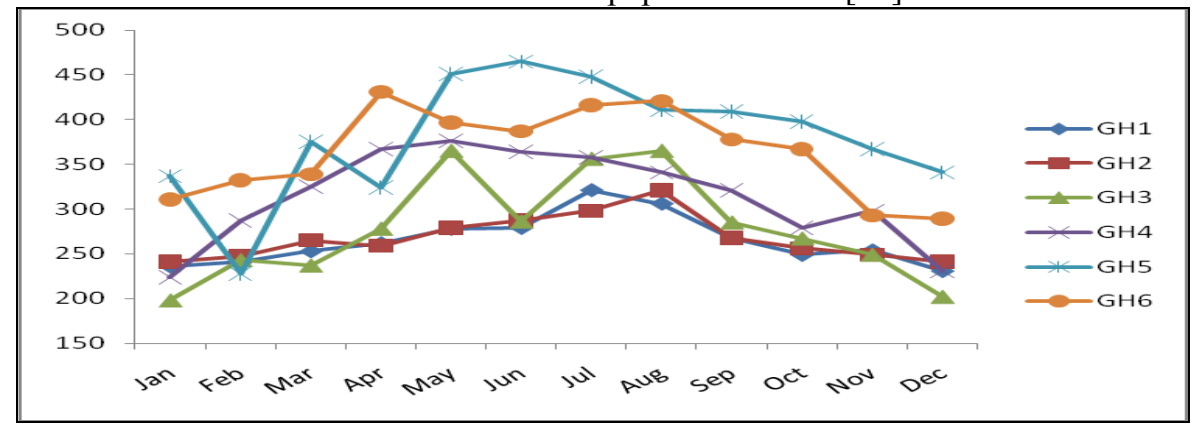

Fig 9: A Graph showing Monthly Variation of EC for all Sampling Ghats

The EC showed significant and positive correlation with Nitrate, Phosphate and Magnesium. EC vs. Nitrate showed max correlation at GH6 $(\mathrm{r}=0.846, \mathrm{p}<0.01)$ and $\min$ at $\mathrm{GH} 1(\mathrm{r}=0.737, \mathrm{p}<0.01)$, EC vs. Phosphate showed max correlation at GH3 $(r=0.843, \mathrm{p}<0.01)$ and $\min$ at $\mathrm{GH} 1(\mathrm{r}=0.371, \mathrm{p}<0.01)$, EC vs. Magnesium showed max correlation at GH4 $(\mathrm{r}=0.847, \mathrm{p}<0.01)$ and $\min$ at GH5 $(\mathrm{r}=0.714, \mathrm{p}<0.01)$.

Nitrate: The average value of Nitrate was observed as $0.33 \pm .32 \mathrm{mg} / \mathrm{l}$ and ranges were detected as $0.035-0.98$ $\mathrm{mg} / \mathrm{l}$ (Table 1, Fig 10). All the values of Nitrate were within permissible range as prescribed by BIS [14] and WHO [15] drinking water standards. Sample of GH1 (Jan) showed lowest value and GH6 (June) had recorded high value of Nitrate. 


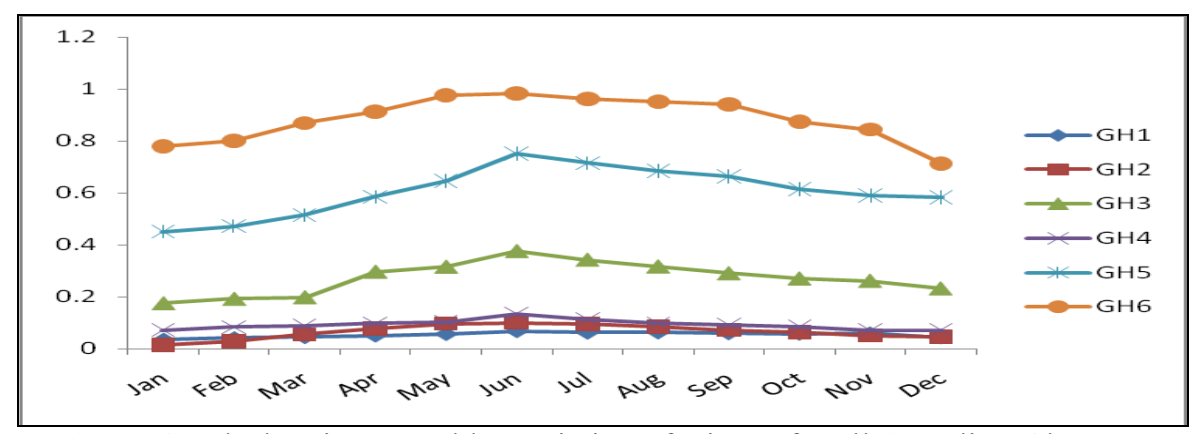

Fig 10: A Graph showing Monthly Variation of Nitrate for all Sampling Ghats

The Nitrate showed significant and positive correlation with Phosphate and Magnesium. Nitrate vs. Phosphate showed max correlation value at GH3 $(\mathrm{r}=0.927, \mathrm{p}<0.01)$ and $\min$ at $\mathrm{GH} 1(\mathrm{r}=0.280, \mathrm{p}<0.01)$, Nitrate vs. Magnesium showed max correlation value at GH3 $(\mathrm{r}=0.951, \mathrm{p}<0.01)$ and $\min$ at $\mathrm{GH} 5(\mathrm{r}=0.736, \mathrm{p}<0.01)$.

Phosphate: Phosphate may occur in surface water as a result of contamination from domestic sewage, detergents, and agricultural effluents with fertilizers. The average value of observed Phosphate was $0.57 \pm .41$ $\mathrm{mg} / \mathrm{l}$ and ranges were detected as $0.035-0.98 \mathrm{mg} / \mathrm{l}$ (Table 1, Fig 10). Minimum value of Phosphate was observed at GH1 (Jan) and max at GH6 (June). All the level of Phosphate wee within the prescribed standards of BIS [14] and WHO [15] (Table 1). Surface water runoff, agriculture runoff; washer man activity could have also contributed to the inorganic phosphate content.

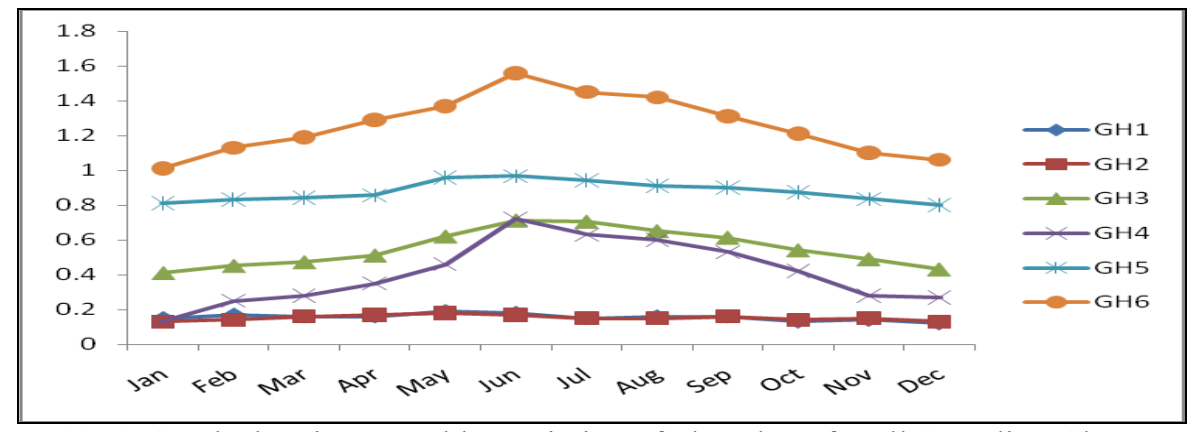

Fig 11: A Graph showing Monthly Variation of Phosphate for all Sampling Ghats

The Phosphate showed significant positive correlation with Magnesium. Phosphate vs. Magnesium showed max correlation value at $\mathrm{GH} 5(\mathrm{r}=0.951, \mathrm{p}<0.01)$ and $\min$ at $\mathrm{GH} 2(\mathrm{r}=0.621, \mathrm{p}<0.01)$,

Magnesium: The average concentration of Magnesium was $12.82 \pm 4.51 \mathrm{mg} / 1$ (range 6.2-24.2 mg/l). Minimum value of Magnesium was observed at GH1 (Jan) and max at GH6 (June). The maximum value of Magnesium was within the limit as per BIS ${ }^{14}$ and $\mathrm{WHO}^{15}$ standards (Table 1, Fig 12).

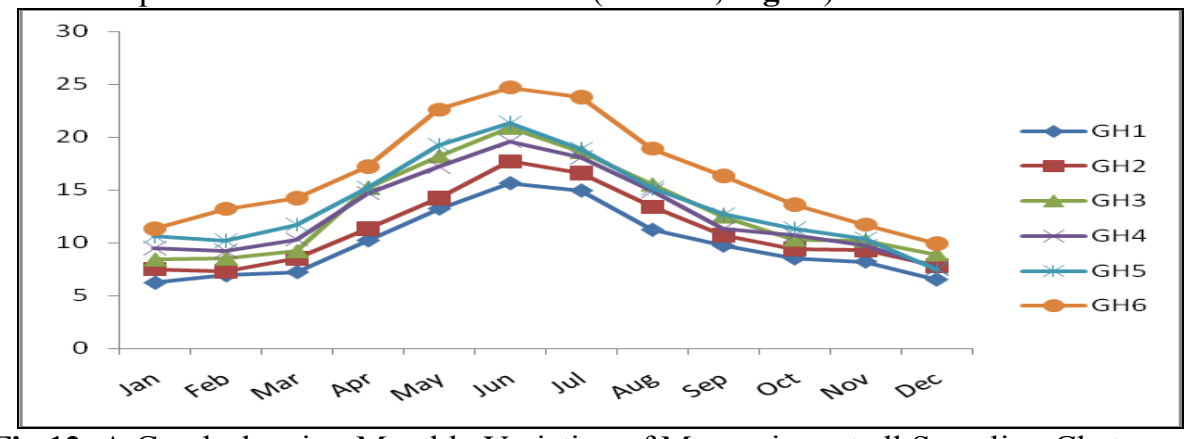

Fig 12: A Graph showing Monthly Variation of Magnesium at all Sampling Ghats

Chromium: The average concentration of Chromium was $0.69 \pm 1.11 \mathrm{mg} / 1$ (range $0.085-6.7 \mathrm{mg} / \mathrm{l}$ ) (range 0.085 $6.7 \mathrm{mg} / \mathrm{l}$ ). Minimum value of Chromium was observed at GH1 (Dec) and max at GH6 (June) (Table 1, Fig 13). The highest value of Chromium was many times greater than max tolerable level as per BIS [14] and WHO [15] recommendations. Ganga, river water samples in Siddhnath ghat crossed the maximum permissible limit, due to heavy mixing of tannery effluent waste. Chromium has no nutritional value, rather they are carcinogenic and 
bio-accumulate up to toxic level to damage essential human and animal organs [25]. Several studies reveal high concentrations of Chromium even in treated effluents as reported earlier [26-27].

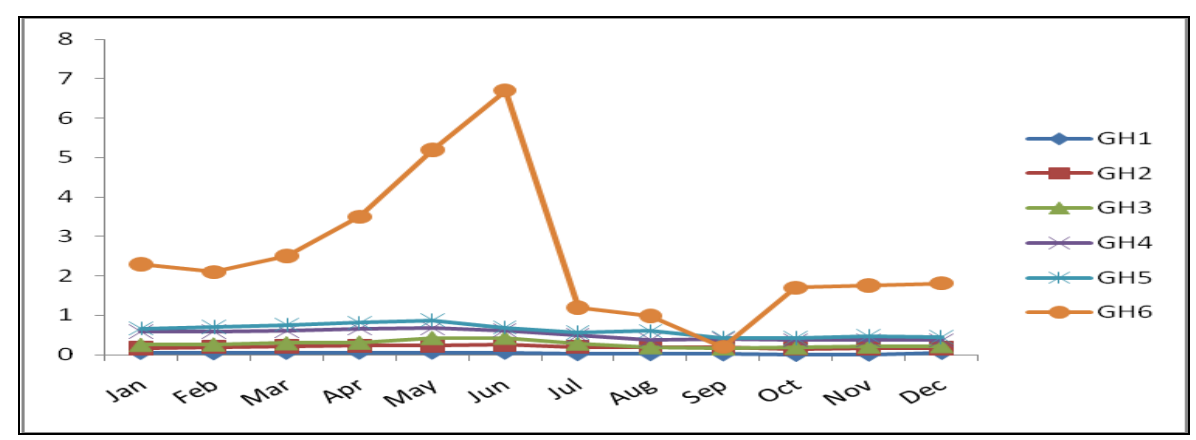

Fig 13: A Graph showing Monthly Variation of Chromium for all Sampling Ghats

Chromium vs Temp, Chloride, Nitrate and Phosphate showed significant positive correlation at GH2 ( $\mathrm{r}=0.711$, $0.744,0.6150 .835, p<0.01)$ respectively and non significant correlation at rest Ghats. Chromium vs $\mathrm{pH}$ showed non significant negative correlation max at GH2 $(\mathrm{r}=-0.520, \mathrm{p}>0.05)$ and $\min$ at GH4 $(\mathrm{r}=-0.164, \mathrm{p}>0.05)$ (Table 3, 5). Chromium vs TA showed non significant correlation max at GH3 $(r=-0.350, p>0.05)$ and $\min$ at GH6 $(r=-$ $0.049, \mathrm{p}>0.05$ ) (Table 4, 7). Chromium vs DO showed non significant negative correlation max at GH3 ( $\mathrm{r}=-$ $0.350, \mathrm{p}>0.05)$ and $\min$ at GH6 $(\mathrm{r}=-0.049, \mathrm{p}>0.05)$ (Table 4, 7). The Chromium showed non significant and positive max correlation with BOD at GH1 $(r=0.112, \mathrm{p}<0.01)$ and $\min$ at $\mathrm{GH} 4(\mathrm{r}=0.014, \mathrm{p}>0.05)$. The Chromium showed non- significant and positive max correlation with TDS at GH1 $(r=0.337, p>0.05)$ and $\min$ at GH5 ( $\mathrm{r}=0.016, \mathrm{p}>0.05)$ (Table2, 7). Chromium vs EC showed non significant correlation max at GH2 ( $\mathrm{r}=0.461$, $\mathrm{p}>0.05)$ and $\mathrm{min}$ at GH5 $(\mathrm{r}=-0.055, \mathrm{p}>0.05)$. The non significant correlation between two parameters means that they are independent to each other.

\section{Conclusion}

The results of present investigation conclude that at Siddhnath ghat (GH6), river is highly polluted due to discharge of tannery effluent and occasional solid waste from tanneries into the river as compared to other location indicated by lower DO levels. The higher levels of all the indicator parameters above the standards are a serious concern for thousands of people living in Jajmau area. The river ecology is also subjected to higher risk of pollutants exposure. Stretch of the river from GH4 (Sarsaiya ghat) to GH6 (Siddhnath ghat) is highly polluted and is not suitable for most of the beneficial uses of water except for irrigation, fish culture and industrial cooling. The correlation analysis on water quality parameters revealed that all parameters are more or less correlated with each other Person's Correlation matrix. It is observed that some of the parameters do not have significant correlation between them indicating the different origin source of pollution. From correlation analysis, the negative relationship DO with other parameters reveals the high organic pollution with anthropogenic activities in the river basin. Thus it can be concluded that the water of the river Ganga at GH6 (Siddhnath ghat) represents serious threat to the ecosystem due to anthropogenic pollution. Since river Ganga is lifeline for people of Kanpur who use its water for bathing and other purposes are at risk. The correlation study and correlation coefficient values can help in selecting a few parameters which could be frequently measured to determine the status of water quality regularly. This will help the regulatory bodies to issue a warning on deteriorating water quality and taking steps to implement control measures so that proper treatment of effluent could be done to minimize contaminants in Ganga river water from Bithoor to Siddhnath ghat in Kanpur.

\section{References:}

[1] Gholami Siamak and S. Srikantaswamy (2009), "Analysis of Agricultural Impact on the Cauvery River Water around KRS Dam" World Applied Sciences Journal, Vol. 6 (8), pp-1157-1169

[2] Ekin Birol and Sukanya Das., Estimating the value of improved wastewater treatment: The case of River Ganga, India J. of Environmental Management.,2010, 91, 2163

[3] Joshi D.M, Bhandari N.S, Kumar Alok and Agrawal Namita., Statistical Analysis of Physico-Chemical parameters of water of river Ganga in Haridwar district., Rasayan.J.Chem. , 2(3)579-587 (2009)

[4] Trivedi Priyanka, Bajpai Amita and Thareja Sukarma, Evaluation of Water Quality: Physico-Chemical characteristics of Ganga river at Kanpur by using correlation study, Nature and Science 1(6), 91-94(2009).

[5] Bhandari N, Nayal K (2008). Correlation study on physicochemical parameters and quality assessment of Kosi river water, Uttarakhand. J. Chem., 5(2): 342-346

[6] Navneet Kumar and Sinha D K, An Approach to River Water Quality Management through Correlation Study among Various Water Quality Parameters-, Int J Environ Sci., 2010, 1(2), 253-259.

[7] Shah, M. C., Shilpkar, P and Sharma, S (2007). Correlation, Regression Study on Physico-chemical parameters and water quality assessment of ground water of MansaTaluka in Gujarat, 19(5) : 3449-3454 
[8] Mulla, J.G., Farooqui, M. and Zaheer, A. A correlation and regression equations among water quality parameters. Int. J. Chem. Sci. 5(2), 2007: 943-952

[9] Sharma S., Dixit s., Jain P., Shah K.W., Vishwakarmar. 2009. Statistical evaluation of hydrobiological parameters of Narmada River water at Hoshangabad City, India. Environmental Monitoring Assessment. Vol. 143p. 195-202. DOI 10.1007/s10661-007-9968-8.

[10] http://en.wikipedia.org/wiki/Kanpur division

[11] SPSS Advanced Models ${ }^{\mathrm{TM}} 17.0 \mathrm{Web}$ site at http://www.spss.com

[12] Adebowale, K.O., Agunbiade, F.O. and Olu-Owolabi, B.I. 2008. Impacts of natural and anthropogenic multiple sources of pollution on the environmental conditions of Onto State Costal Water Nigeria. EJEAFChe,7 (4): 2797-2811

[13] Pejman A.H., Bidhendi G. R. N., Karbassi A. R., Mehrdadi N. and Bidhendi M.E., (2009), "Evaluation of spatial and seasonal variations in surface water quality using multivariate statistical techniques", International Journal of Environmental Science and Technology, Vol. 6, No. 3, pp. 467-476.

[14] Bureau of Indian Standards, Indian Standards (IS:10500) Drinking Water Specification: New Delhi (2004)

[15] World Health Organization; Guidelines for drinking Water Quality: Vol.1, Recommendation 2nd Edition;Geneva, WHO (2008)

[16] Chang, H. (2008), "Spatial analysis of water quality trends in the Han River basin, South Korea", Water Research, Vol.42, No.13,pp.3285-330

[17] Srivastava Anukool, Srivastava Shivani, (2011), Assessment of Physico-Chemical properties and sewage pollution indicator bacteria in surface water of River Gomti in Uttar Pradesh, International Journal of Environmental Sciences, 2(1), 325-336.

[18] Usharani, K; Umarani, K; Ayyasamy, PM; Shanthi, K; Lakshmanaperumalsamy, P, "Physico-Chemical and Bacteriological Characteristics of Noyyal River and Ground Water Quality of Perur, India”, J. Appl. Sci. Environ. Manage., 1vol. 4, no. 2, pp. 29-35, 2010

[19] Ismail BS (2007) A Physico-chemical assessment of the Bebar river, Pahang, Malaysia. Global J Environ Res 1:07-11.

[20] Bhatti, M.T. \& Latif, M. (2011), Assessment of water quality of a river using an indexing approach during the low-flow season. IrrigationDrainage60: 103-114.

[21] Bhadula, S. and Joshi, B.D. An Assessment of the impact of sewer drains on the main canal of River Ganga, within Haridwar city, Uttarakhand, India.Researcher. 2012.4(1):7-14.

[22] Garizi A. Z., Sheikh V. and Sadoddin A., (2011), "Assessment of seasonal variations of chemical characteristics in surface water using multivariate statistical methods", International Journal of Environmental Science and Technology, Vol. 8, No.3,pp.581-592

[23] Madhab Borah et al Study of some Physico-Chemical Parameters of Pond and River water with reference to Correlation Study/Int. J. Chem Tech Res.2011,3(4)

[24] Srivastava A., Kumar, R., Gupta ,V., Agarwal, G., Srivastava, S and Singh, I (2011).Water quality assessment of Ramganga River at Moradabad by Physico-Chemical Parameters Analysis, VSRD-TNTJ 2 (3) 119-127.

[25] A. N. Amadi, P. I. Olasehinde, E. A. Okosun and J. Yisa. Assessment of the water quality index of Otamiri and Ora-miriukwa Rivers. Physics International, 2010,1(2),116 - 123

[26] Rai et al Heavy metal and microbial pollution of the River Ganga:A case study of water quality at Varanasi Aquatic Ecosystem, 13(4):352-361, 2010

[27] Kar, D., Sur, P., Mandal, S. K., Saha, T.and Kole, R. K. (2008). Assessment of heavy metal pollution in surface water. International Journal of Environment Science and Technology. 5(1), 119-124

\begin{tabular}{|c|c|c|c|c|c|c|c|c|c|c|c|c|}
\hline & Temp & $\mathrm{PH}$ & Alkalinity & $\mathrm{DO}$ & $\mathrm{BOD}$ & TDS & Chloride & $\mathrm{FC}$ & $\mathrm{NO}^{-1}$ & $\mathrm{PO}^{-3}$ & $C_{r}$ & $M$ \\
\hline & & & & & & & & & & & & \\
\hline Temp & 1 & $-.709 * *$ & $-.722 * *$ & $.805^{* *}$ & $.991^{* *}$ & $.774 * *$ & $.872 * *$ & $.844 * *$ & $.774 * *$ & $.616^{*}$ & 0.101 & $.971 * *$ \\
\hline $\mathrm{PH}$ & & 1 & $.731 * *$ & $.799 * *$ & $-722 * *$ & $-934 * *$ & $-.636^{*}$ & $-.704 *$ & $-727 * *$ & 0.449 & 0.33 & $-.703^{*}$ \\
\hline TA & & & 1 & $.842 * *$ & $-708 * *$ & $-843 * *$ & $-.588 *$ & $\begin{array}{l}- \\
.770 * *\end{array}$ & $-.635^{*}$ & 0.324 & 0.176 & $-.635^{*}$ \\
\hline DO & & & & & $-839 * *$ & $-895 * *$ & $-.694 *$ & $\begin{array}{l}- \\
.828 * *\end{array}$ & $-837 * *$ & -0.27 & 0.275 & $\begin{array}{c}- \\
.747 * *\end{array}$ \\
\hline BOD & & & & & 1 & $.791 * *$ & $.853 * *$ & $.813 * *$ & $.779 * *$ & $.600 *$ & 0.112 & $.955 * *$ \\
\hline TDS & & & & & & 1 & $.670 *$ & $.758 * *$ & $.793 * *$ & 0.299 & $\begin{array}{r}- \\
0.337\end{array}$ & $.758 * *$ \\
\hline Chloride & & & & & & & & $.877 * *$ & $.583 *$ & 0.49 & 0.097 & $.884 * *$ \\
\hline $\mathrm{EC}$ & & & & & & & & 1 & $.737 * *$ & 0.371 & -0.25 & $.837 * *$ \\
\hline $\mathrm{NO}_{3}{ }^{-1}$ & & & & & & & & & 1 & 0.23 & $\begin{array}{r}- \\
0.445\end{array}$ & $.801 * *$ \\
\hline $\mathrm{PO}_{4}{ }^{-3}$ & & & & & & & & & & 1 & 0.45 & 0.537 \\
\hline $\mathrm{Cr}$ & & & & & & & & & & & 1 & 0.021 \\
\hline
\end{tabular}

**.Correlation is significant at the 0.01 level (2-tailed)

*. Correlation is significant at the 0.05 level (2-tailed) 
Correlation Study For The Assessment Of Water Quality and Its Parameters Of Ganga River,Kanpur,

\begin{tabular}{|c|c|c|c|c|c|c|c|c|c|c|c|c|}
\hline \multicolumn{13}{|c|}{ Table 3:Pearson Correlations among the different parameters of surface water in Ganga river at GH2 (Rani ghat) } \\
\hline & Temp & $\mathrm{PH}$ & TA & DO & BOD & TDS & Chloride & $\mathrm{EC}$ & $\mathrm{NO}_{3}^{-1}$ & $\mathrm{PO}_{4}^{-3}$ & $\mathrm{Cr}$ & $\mathrm{Mg}$ \\
\hline Temp & 1 & $-.797 * *$ & $-.705^{*}$ & $-.579 *$ & 0.493 & $.756^{* * *}$ & $.799 * *$ & $.820 * *$ & $.935^{* *}$ & $.712^{* *}$ & $.711 * *$ & $.969^{* *}$ \\
\hline PH & & 1 & $.651^{*}$ & $.857 * *$ & $-.664 *$ & $\begin{array}{c}- \\
.880^{* *}\end{array}$ & -0.465 & $-.658^{*}$ & $\begin{array}{c}- \\
.858^{* *}\end{array}$ & -0.507 & -0.283 & $\begin{array}{c}- \\
.766^{* *}\end{array}$ \\
\hline TA & & & 1 & $.716^{* *}$ & $-.633 *$ & $-.674 *$ & -0.423 & ${ }^{-}-815^{* *}$ & $\overline{-}^{-} 1^{* *}$ & -0.4 & -0.35 & $-.672 *$ \\
\hline DO & & & & 1 & $\begin{array}{c}- \\
.866^{* *}\end{array}$ & ${ }^{-} 85^{* *}$ & -0.302 & $-.696^{*}$ & $-.669^{*}$ & -0.223 & 0.048 & $-.594 *$ \\
\hline BOD & & & & & 1 & $.751 * *$ & 0.4 & $.663^{*}$ & 0.529 & -0.042 & -0.148 & $.578^{*}$ \\
\hline TDS & & & & & & 1 & 0.46 & $.715^{* *}$ & $.857 * *$ & 0.488 & 0.176 & $.762^{* *}$ \\
\hline Chloride & & & & & & & 1 & $.748^{* *}$ & $.701 *$ & $.585^{*}$ & $.744 * *$ & $.810^{* *}$ \\
\hline $\mathrm{EC}$ & & & & & & & & 1 & $.780 * *$ & 0.442 & 0.461 & $.799 * *$ \\
\hline $\mathrm{NO}_{3}{ }^{-1}$ & & & & & & & & & 1 & $.757 * *$ & $.615^{*}$ & $.907 * *$ \\
\hline $\mathrm{PO}_{4}^{-3}$ & & & & & & & & & & 1 & $.835 * *$ & $.621^{*}$ \\
\hline $\mathrm{Cr}$ & & & & & & & & & & & 1 & $.632 *$ \\
\hline
\end{tabular}

**.Correlation is significant at the 0.01 level (2-tailed)

*. Correlation is significant at the 0.05 level (2-tailed)

\begin{tabular}{|c|c|c|c|c|c|c|c|c|c|c|c|c|}
\hline \multicolumn{13}{|c|}{ Table 4:Pearson Correlations among the different parameters of surface water in Ganga river at GH3 (Permat ghat) } \\
\hline & Temp & $\mathrm{PH}$ & TA & DO & BOD & TDS & Chloride & EC & $\mathrm{NO}_{3}^{-1}$ & $\mathrm{PO}_{4}^{-3}$ & $\mathrm{Cr}$ & $\mathrm{Mg}$ \\
\hline Temp & 1 & $\begin{array}{c}- \\
.966^{* *}\end{array}$ & $-.761 * *$ & $\begin{array}{c}- \\
.863 * * \\
\end{array}$ & $.719 * *$ & $.755^{* *}$ & $.849 * *$ & $.852 * *$ & $.916^{* *}$ & $.951 * *$ & 0.567 & $.969^{* *}$ \\
\hline $\mathrm{PH}$ & & 1 & $.651^{*}$ & $.887 * *$ & $\begin{array}{c}- \\
.750^{*} * *\end{array}$ & $\begin{array}{c}- \\
.721^{* *}\end{array}$ & $-.794 * *$ & $\begin{array}{c}- \\
808 * *\end{array}$ & $\begin{array}{c}- \\
.964 * *\end{array}$ & $\begin{array}{c}- \\
.944^{* *}\end{array}$ & -0.52 & $\begin{array}{c}- \\
.952^{* *}\end{array}$ \\
\hline TA & & & 1 & $.683^{*}$ & -0.552 & $\begin{array}{c}- \\
.865^{* *} \\
\end{array}$ & $-.613 *$ & $\begin{array}{c}- \\
.750^{* *}\end{array}$ & $-.634 *$ & $\begin{array}{c}- \\
.737^{* *} \\
\end{array}$ & $\begin{array}{c}- \\
0.111 \\
\end{array}$ & $-.630^{*}$ \\
\hline DO & & & & 1 & $\begin{array}{c}- \\
.943^{* *} \\
\end{array}$ & $\begin{array}{c}- \\
.807^{*} * * \\
\end{array}$ & $-.694 *$ & $\begin{array}{c}- \\
.747 * * \\
\end{array}$ & $\begin{array}{c}- \\
.903^{*} * \\
\end{array}$ & $\begin{array}{c}- \\
.967^{* *} \\
\end{array}$ & $\begin{array}{c}-\overline{-} \\
0.178 \\
\end{array}$ & $\begin{array}{c}- \\
.805^{* *}\end{array}$ \\
\hline BOD & & & & & 1 & $.760 * *$ & $.652 *$ & $.675^{*}$ & $.815^{* *}$ & $.883^{* *}$ & 0.007 & $.688^{*}$ \\
\hline TDS & & & & & & 1 & $.736^{* *}$ & $.737 * *$ & $.767 * *$ & $.819 * *$ & $\begin{array}{c}-\overline{-} \\
0.025 \\
\end{array}$ & $.690 *$ \\
\hline Chloride & & & & & & & 1 & $.842 * *$ & $.739 * *$ & $.828^{* *}$ & 0.454 & $.855^{* *}$ \\
\hline EC & & & & & & & & 1 & $.770 * *$ & $.843^{* *}$ & 0.289 & $.792 * *$ \\
\hline $\mathrm{NO}_{3}{ }^{-1}$ & & & & & & & & & 1 & $.927 * *$ & 0.386 & $.931^{* *}$ \\
\hline $\mathrm{PO}_{4}^{-3}$ & & & & & & & & & & 1 & 0.343 & $.902 * *$ \\
\hline $\mathrm{Cr}$ & & & & & & & & & & & 1 & $.641 *$ \\
\hline
\end{tabular}

**.Correlation is significant at the 0.01 level (2-tailed)

*. Correlation is significant at the 0.05 level (2-tailed)

\begin{tabular}{|c|c|c|c|c|c|c|c|c|c|c|c|c|}
\hline \multicolumn{13}{|c|}{ Table 5:Pearson Correlations among the different parameters of surface water in Ganga river at GH4 (Sarsaiya ghat) } \\
\hline & Temp & $\mathrm{PH}$ & TA & DO & BOD & TDS & Chloride & $\mathrm{EC}$ & $\mathrm{NO}_{3}^{-1}$ & $\mathrm{PO}_{4}^{-3}$ & $\mathrm{Cr}$ & $\mathrm{Mg}$ \\
\hline Temp & 1 & $\begin{array}{c}- \\
.621 * \\
\end{array}$ & $-.681 *$ & $\begin{array}{c}- \\
.815^{* *} \\
\end{array}$ & $.912 * *$ & $.859 * *$ & $.829 * *$ & $.896 * *$ & $.928 * *$ & $.898 * *$ & 0.3 & $.936^{* *}$ \\
\hline $\mathrm{PH}$ & & 1 & $.824 * *$ & $.711 * *$ & $\begin{array}{c}- \\
.779^{* *} \\
\end{array}$ & $\begin{array}{c}- \\
.742^{* *} \\
\end{array}$ & -0.421 & $-.676^{*}$ & -0.473 & $-.677 *$ & 0.164 & -0.528 \\
\hline TA & & & 1 & $.719 * *$ & $\begin{array}{c}- \\
.812^{* *}\end{array}$ & $-.648^{*}$ & $-.659 *$ & $-.699 *$ & $-.613^{*}$ & $\begin{array}{c}- \\
.787 * * \\
\end{array}$ & 0.133 & $-.635 *$ \\
\hline DO & & & & 1 & $\begin{array}{c}- \\
.818^{* *}\end{array}$ & $\begin{array}{c}- \\
.832^{* *}\end{array}$ & $-.659 *$ & $\begin{array}{c}- \\
.734 * * \\
\end{array}$ & $\begin{array}{c}- \\
.784 * * \\
\end{array}$ & $\begin{array}{c}- \\
.853^{* *}\end{array}$ & $\begin{array}{c}- \\
0.036 \\
\end{array}$ & $\begin{array}{c}- \\
.726^{* *} \\
\end{array}$ \\
\hline BOD & & & & & 1 & $.849 * *$ & $.765^{* *}$ & $.827 * *$ & $.838 * *$ & $.938 * *$ & 0.014 & $.862^{* *}$ \\
\hline TDS & & & & & & 1 & $.634^{*}$ & $.687 *$ & $.722 * *$ & $.883 * *$ & $\begin{array}{c}- \\
0.081 \\
\end{array}$ & $.745^{* *}$ \\
\hline Chloride & & & & & & & 1 & $.759 * *$ & $.812 * *$ & $.787 * *$ & 0.327 & $.914 * *$ \\
\hline $\mathrm{EC}$ & & & & & & & & 1 & $.785 * *$ & $.709^{* *}$ & 0.431 & $.847 * *$ \\
\hline $\mathrm{NO}_{3}{ }^{-1}$ & & & & & & & & & 1 & $.867 * *$ & 0.407 & $.926^{* *}$ \\
\hline $\mathrm{PO}_{4}^{-3}$ & & & & & & & & & & 1 & $\begin{array}{c}- \\
0.061 \\
\end{array}$ & $.825^{* *}$ \\
\hline $\mathrm{Cr}$ & & & & & & & & & & & 1 & 0.423 \\
\hline
\end{tabular}

**.Correlation is significant at the 0.01 level (2-tailed)

*. Correlation is significant at the 0.05 level (2-tailed) 
Correlation Study For The Assessment Of Water Quality and Its Parameters Of Ganga River,Kanpur,

\begin{tabular}{|c|c|c|c|c|c|c|c|c|c|c|c|c|}
\hline \multicolumn{13}{|c|}{ Table6:Pearson Correlations among the different parameters of surface water in Ganga river at GH5 (Nanarao ghat) } \\
\hline & Temp & $\mathrm{PH}$ & TA & DO & BOD & TDS & Chloride & EC & $\mathrm{NO}_{3}^{-1}$ & $\mathrm{PO}_{4}^{-3}$ & $\mathrm{Cr}$ & $\mathrm{Mg}$ \\
\hline Temp & 1 & $.966^{* *}$ & $.853^{-} * *$ & $.752 * *$ & $.896^{* *}$ & $.831 * *$ & $.845^{* *}$ & $.773 * *$ & $.801 * *$ & $.942 * *$ & 0.377 & $.967 * *$ \\
\hline PH & & 1 & $.782 * *$ & $.713^{* *}$ & $\stackrel{-}{.} 854^{* *}$ & $.763 * *$ & $-.799 * *$ & $\begin{array}{c}- \\
.790^{* * *} \\
\end{array}$ &.$-\overline{8}$ & $.938^{-}$ & $0 . \overline{2} 76$ & $.940^{* *}$ \\
\hline TA & & & 1 & $.815^{* *}$ & $\overline{-}$. & ${ }^{-}-880^{* *}$ & -0.574 & $-.705^{*}$ & $\begin{array}{c}- \\
.809^{* * *}\end{array}$ & $\begin{array}{c}- \\
.838^{* *}\end{array}$ & $\begin{array}{c}- \\
0.092 \\
\end{array}$ & $\begin{array}{c}- \\
.746^{* *} \\
\end{array}$ \\
\hline DO & & & & 1 & $\begin{array}{c}- \\
896^{* *}\end{array}$ & $\begin{array}{c}- \\
.960^{* *}\end{array}$ & $-.677^{*}$ & $-.625 *$ & $\begin{array}{c}- \\
.770 * *\end{array}$ & $\begin{array}{c}- \\
.723^{* *}\end{array}$ & 0.115 & $-.684 *$ \\
\hline BOD & & & & & 1 & $.954 * *$ & $.770^{* *}$ & $.728 * *$ & $.896 * *$ & $.865 * *$ & 0.076 & $.829 * *$ \\
\hline TDS & & & & & & 1 & $.756^{* *}$ & $.652 *$ & $.814 * *$ & $.788 * *$ & 0.016 & $.754 * *$ \\
\hline Chloride & & & & & & & 1 & 0.529 & $.656^{*}$ & $.765 * *$ & 0.355 & $.879 * *$ \\
\hline $\mathrm{EC}$ & & & & & & & & 1 & $.828 * *$ & $.810 * *$ & $\begin{array}{c}- \\
0.055\end{array}$ & $.714 * *$ \\
\hline $\mathrm{NO}_{3}^{-1}$ & & & & & & & & & 1 & $.842 * *$ & -0.18 & $.736^{* *}$ \\
\hline $\mathrm{PO}_{4}^{-3}$ & & & & & & & & & & 1 & 0.233 & $.931 * *$ \\
\hline $\mathrm{Cr}$ & & & & & & & & & & & 1 & 0.467 \\
\hline
\end{tabular}

**.Correlation is significant at the 0.01 level (2-tailed).

*. Correlation is significant at the 0.05 level (2-tailed)

\begin{tabular}{|c|c|c|c|c|c|c|c|c|c|c|c|c|}
\hline \multicolumn{13}{|c|}{ Table 7:Pearson Correlations among the different parameters of surface water in Ganga river at GH6 (Siddhnath ghat) } \\
\hline & Temp & $\mathrm{PH}$ & TA & $\mathrm{DO}$ & BOD & TDS & Chloride & $\mathrm{EC}$ & $\mathrm{NO}_{3}^{-1}$ & $\mathrm{PO}_{4}^{-3}$ & $\mathrm{Cr}$ & $\mathrm{Mg}$ \\
\hline Temp & 1 & $.989 * *$ & $.792 * *$ & $.905^{* *}$ & $.737 * *$ & $.899 * *$ & $.755^{* * *}$ & .789 ** & $.931 * *$ & $.966^{* * *}$ & 0.53 & $.982 * *$ \\
\hline $\mathrm{PH}$ & & 1 & $.814^{* *}$ & $.868^{* *}$ & $.740^{* *}$ & $890^{* *}$ & $-.714 * *$ & $838^{* *}$ & $.936^{* * *}$ & $.963^{* *}$ & 0.517 & $.979 * *$ \\
\hline TA & & & 1 & $.750^{* *}$ & $.849 * *$ & $.888^{* *}$ & $-.633^{*}$ & $.897 * *$ & $.870 * *$ & $.868^{* *}$ & 0.049 & $.786 * *$ \\
\hline DO & & & & 1 & $-.703 *$ & $.832^{* * *}$ & $-.771 * *$ & $.741 * *$ & $.871^{* *}$ & $.896 * *$ & 0.415 & $.854 * *$ \\
\hline BOD & & & & & 1 & $.756^{* *}$ & $.614^{*}$ & $.674 *$ & $.792 * *$ & $.832 * *$ & 0.082 & $.708^{*}$ \\
\hline TDS & & & & & & 1 & $.697 *$ & $.836 * *$ & $.868 * *$ & $.919 * *$ & 0.249 & $.935 * *$ \\
\hline Chloride & & & & & & & 1 & 0.567 & $.697 *$ & $.801^{* *}$ & 0.465 & $.725 * *$ \\
\hline $\mathrm{EC}$ & & & & & & & & 1 & $.846^{* *}$ & $.829^{* *}$ & 0.191 & $.797 * *$ \\
\hline $\mathrm{NO}_{3}{ }^{-1}$ & & & & & & & & & 1 & $.914^{* *}$ & 0.323 & $.895 * *$ \\
\hline $\mathrm{PO}_{4}{ }^{-3}$ & & & & & & & & & & & 0.401 & $.951 * *$ \\
\hline $\mathrm{Cr}$ & & & & & & & & & & & & 0.506 \\
\hline
\end{tabular}

**.Correlation is significant at the 0.01 level (2-tailed).

*. Correlation is significant at the 0.05 level (2-tailed) 